\title{
Research on the Economic Strategy of Cross-Border Electronic Commerce for Middle and Small-Sized Enterprises
}

\author{
Chongjie Zhang \\ Huanghe Science And Technology College,Zhengzhou,Henan,45000 China \\ Northwest University,Xi'An,Shaanxi,71000 China
}

\begin{abstract}
In this paper, we conduct research on the economic strategy of the cross-border electronic commerce for the middle and small-sized enterprises. Cross-border e-commerce in our country has more than ten years of development history, is an integral part of foreign trade and economy, also emerged many operation mode, summarizes recent years cross-border electrical business operation mode, the cross-border e-commerce law of development as is of great significance to the development of Chinese cross-border electricity, and an important content of the rich e-commerce discipline. In this article, through analysis of the existing cross-border electric business platform operation, we summarize the operation mode of the cross-border electricity, cross-border e-commerce business to give reference to small and medium-sized enterprises. In the future research, we will enhance the current research pattern with the introduction and combination of the latest theory.
\end{abstract}

Keywords-Economic Strategy, Cross-Border, Electronic Commerce, Middle and Small-Sized.

\section{Introduction}

Look from broad sense, the cross-border electricity basic equivalent electric business of foreign trade, refers to the trading main body, belong to different passes condition by means of electronic commerce in the traditional import and the export trade exhibition, negotiation and sale link electronically, and through the cross-border logistics delivery goods, complete the transaction of a kind of international business activities. Cross-border electricity is the application of e-commerce in the import and export trade, the traditional international trade business process electronic, digital and networked. It involves electronic trade goods, online data transmission, electronic funds transfer, electronic documents, etc. Say simply, cross-border electricity is some Chinese exporters using email and instant messaging tool to communicate with overseas buyers, businesses and individuals to sellers and overseas buyers for small trade through the network [1-2].

According to the literature review, current situation and developmental challenges for cross-border electronic commerce could be summarized as the follows. (1) Trading main body of market access. Although cross-border electricity and payment will be mapped to the business world, prompted the economic and financial information and the capital chain focused on the data platform, but if trading main body lack sufficient economic strength, the credit crisis, system fault, the problem such as the information leakage, consequences of foreign exchange funds leads to customers. So, cross-border electricity and means of payment to participate in the main body of market access van management is extremely important and urgent. (2) Regulatory issues. Customs supervision cross-border electricity insurmountable difficulties, the flow of goods regulated by the national code of conduct, import and export goods exceeds the customs regulation number, asked to declare. Goods of red tape and costs to increase the time cost of consumers, economic cost and so on, at the same time, declare unqualified goods are stranded in the phenomenon of the consumers can't receive the goods in the customs is often happen. (3) Logistics problems. Cross-border electricity, under the rapid development of the logistics transportation 
channel unprepared and make logistics development lags behind. Small cross-border e-commerce transactions, with the rapid development of cross-border e-commerce logistics stagnate that needs a balancing security, speed, cost, or even change after-sales logistics service products.

Previously, due to cross-border electricity limited by policy regulation, on the one hand, the user's purchase requirements need to be fulfilled as on the other hand the policy determines the efficiency of the market to meet user did not significantly improve. But now, from the perspective of mind-blowing customs issued multiple files, government level recognition of cross-border electricity and encourage more and more obvious. At present, around start actively formulate implementation plan, supporting policies. For the customs clearance by the express mail or email the cross-border trade e-commerce is difficult to fast customs clearance, foreign exchange settlement and tax rebates and other issues, the general administration of basic customs organization about demonstration city for cross-border trade e-commerce service pilot work that the cross-border e-commerce related basic information standards, management system, improve the level of customs management and service. Pilot work on business innovation policy, not only suitable for cross-border e-commerce development management system, and has carried on the innovation from the informationization means, relying on the advantage of the electronic port coordination mechanism and platform construction, realizes the port authorities and the electricity, payment, logistics and other business synergy and data sharing to solve the problems of the general contented cross-border e-commerce [3-4].

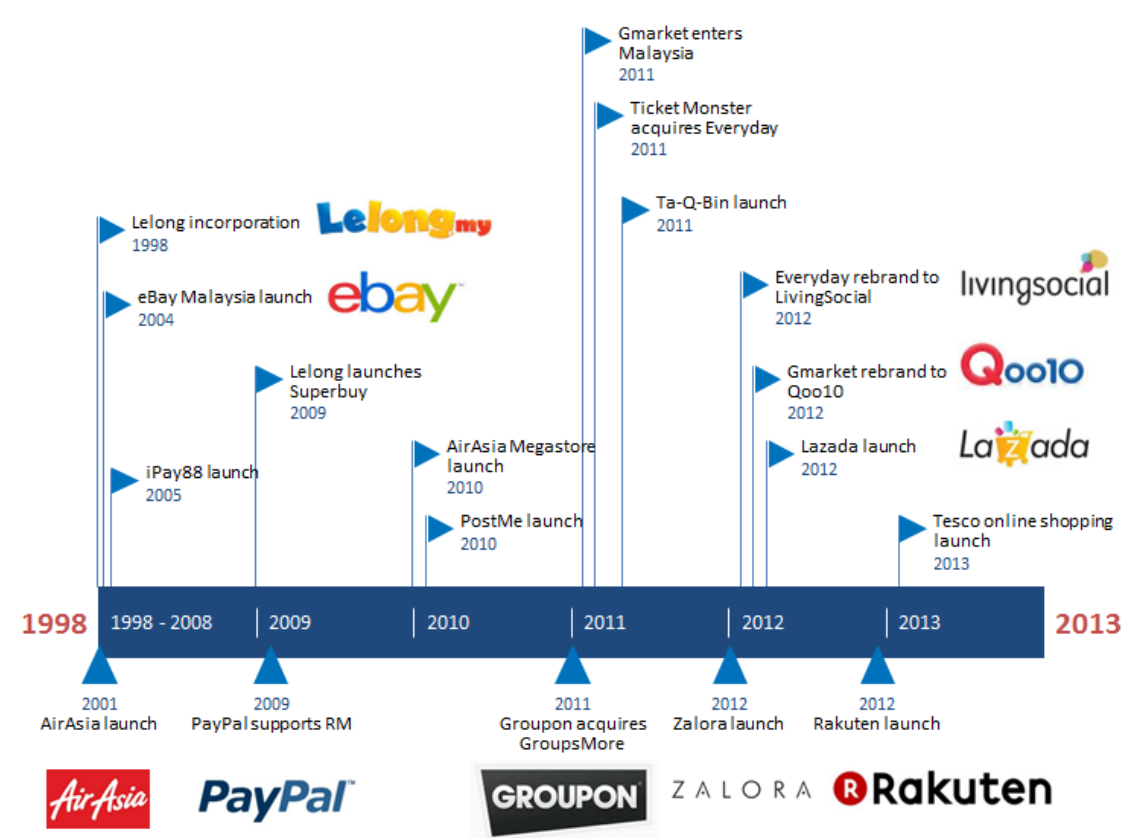

Figure 1. The Developmental Pattern of the Famous Cross-Border Electronic Commerce Modes

In this paper, we conduct research on the economic strategy of cross-border electronic commerce for middle and small-sized enterprises. An enterprise wants to grasp the future, to be built to last as is about to change, fundamentally challenge myself, to constantly challenge their own ideas, their own ideas, and constantly spread new ideas. In the later sections, our research combines the innovative and the overall development of the cross-border electronic commerce to enhance the performance. 


\section{The Proposed Methodology}

The Principles of the Enterprise Strategy. Today, along with speeding up of the process of global integration, the globalization of market competition that has not only is the technology and quality of competition, but the wisdom and the competition of business management. This battle as a result, the winner will take more market share than others, obtain bigger development opportunities. More and more enterprises realize that in the fierce international market competition and the complex external environment, in order to survive and long-term development, we must stand at the height of the global to grasp the future, through enhancing its advantages, and dynamic balance of internal resources and external environment. For vast number of small and medium-sized enterprises, this is a real challenge of life and death. Therefore, we should follow the listed issues to optimize our strategy.

- Corporate policy. Enterprise policy refers to the general enterprise behavior it summarizes the established goal, frame structure of selection strategy and implementation strategy. Enterprise policy is the premise for strengthen strategic management, therefore, when making enterprise policy that is an important question to consider: the policy should help the business goal of the implementation of the strategy implementation and success [5].

- Set up diversified strategy. With the increasingly development of information technology and the wide application of the organizational structure to the flat direction evolution, the spread of information means and channels of the communication which also becomes the popular and diversification this allows the throughout the enterprise internal, had the power of information tend to be generally equal and of the same features.

- To have accurate strategic positioning. Small and medium-sized enterprises affected by the product's life cycle generally cannot easily make diversification management. So, small and medium-sized enterprise is to choose a particular industry as a whole, or in the industry of the link should be after careful scrutiny, grasp well, here is mainly using comparative advantage.

Strategy map and describe the strategic task of execution of the bear. At the same time may not be appropriate for strategies, try to format the infinite of the divergence strategy generation process, on the other hand, lack of description of core strategic issues, which may hinder the strategic dialogue, weaken the general creative strategy and countermeasures. 


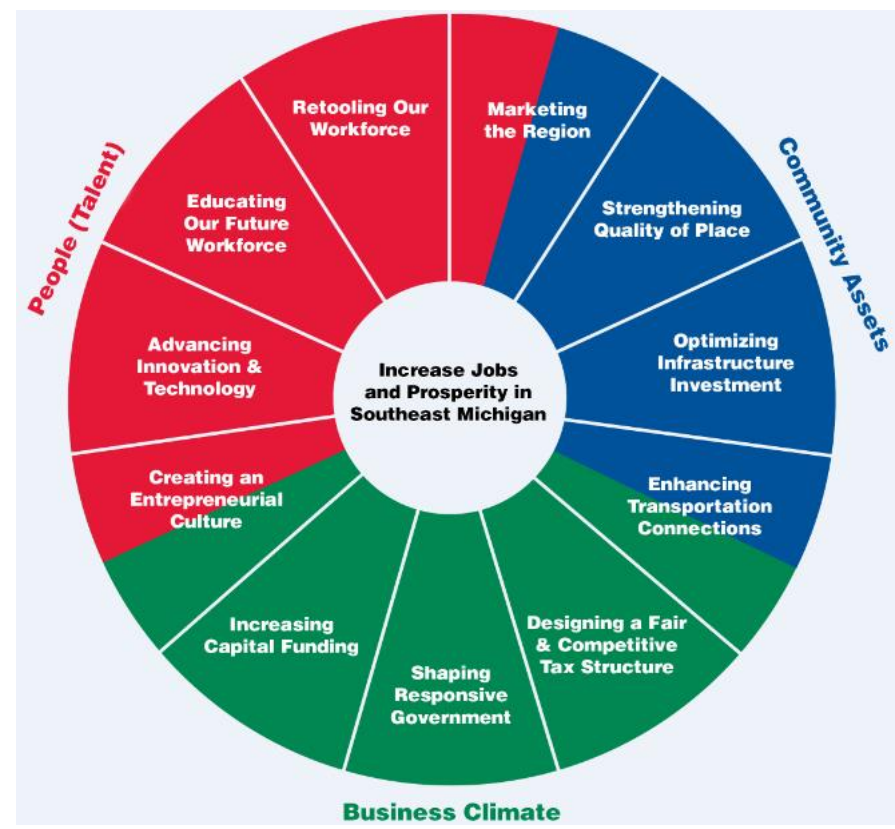

Figure 2. The Sample Enterprise Strategy from the US Perspective

\section{The Electronic Commerce Development}

Trend. At present, most the small and medium-sized enterprises to extraordinary development speed into e-commerce. Though from different industries, pursue different goals and the economic development path, but all in using this new e-commerce platform, inject new vitality to the traditional industry. The perfection of the electronic commerce and the expansion of territory also has a certain role in promoting, especially for the electronic commerce connotation of the business purposes, the evolution, not only the radiation to the product marketing, logistics and distribution, electronic payment, the integration of the sales channel elements such as reasonable, and this model is greatly satisfy the demand for development of small and medium-sized enterprises. Both makes up for the small and medium-sized enterprises in technology, the defect of experience has become the weapon with which to cope with the economic globalization competition will choose and destined to become influence towards an indicator of future economic pulse.

Online shopping is just a small part of the e-commerce, e-commerce and complete process is the use of modern information technology business activities of electronic process. The developmental trend of the business model could be summarized as the following aspects. (1) E-commerce market positioning will be even more differentiation. At the end of the development, the electronic commerce will not be on the products and prices, and should be on the service competition. The high quality service and good customer relationship management is the electronic commerce merchants have the magic weapon to win. (2) Industry e-commerce will become the mainstream. This is because the e-commerce only combines with traditional industry to achieve the greater development. E-commerce can change industry's business and management environment, management mode and organization structure, the industry value chain, etc. (3) E-commerce will further expand the application of depth. Enterprises to create, to form a new value chain, new and old upstream and downstream stakeholders together, form a more efficient strategic alliance to seek greater common interests. (4) E-commerce sites will be merger boom. These good foundations and the development prospect of basic website development, complementary acquisition strategy must be adopted to form an alliance. 


\section{The Development of Small and the} Medium-Sized Enterprises. Small and the medium-sized enterprise is the cell of the national economy, is the most vigor and vitality of the market economy. It is an important force to promote the development of national economy is a stable source of revenue, in promoting technology innovation, regional economic development, industrial structure adjustment, promote employment, rural labor transfer, promote social harmony and so on and so on has the very vital significance. With the constant improvement of the China's socialist market economy system, accelerate the development of small and medium-sized enterprises is the inevitable choice of market economy. Because of the investment needed for small business is not big, to take the requirements of the national resources is not high, and the investment and the relatively short work period and it has become a small a direct cause of high production rate as small business is responsive to the market.

Small businesses have strong power of technology innovation and institution innovation. Due to the small face of external competition pressure is relatively large enterprise bigger as this gives small businesses strive to win by new powerful inner dynamic laughed. The small business environment adaptiveness simple layout requirements, the requirement of resource acquisition are not high can be widely distributed in various environmental conditions and this makes small businesses became the main force of local economic development. To improve the economic layout, coordination of regional economic development important means [6-8].

The Future of Cross-Border Electronic Commerce. Cross-border business is to promote the international economic integration, trade important driver of globalization, cross-border electricity not only makes consumers more easily to buy cheap and fine goods all over the world, for small and medium-sized enterprises, cross-border electricity greatly broaden business channel, save operating costs, to help small and medium-sized more easily into international market, promote international resource optimal allocation and promoting world economic prosperity and win-win between the enterprise. Based on the prior discussion, we could summarize the future of the business pattern as the follows. (1) The diversity of types of merchandise sales target and market. Cross-border, the rapid development of electrical business promoted the general international express delivery, international payments and the prosperity of international cross-border retail market, cross-border electricity is becoming more and more broad range of goods, from small goods to furniture, automobile and other large products is also very normal. In addition, the international cross-border electricity target market is more and more widely, including Russia, Brazil, Saudi Arabia, South America, Southeast Asia and other electrical business enterprises of underdeveloped countries and regions, is now on cross-border electricity with the network demand. (2) Mobile commerce in the cross-border electricity business increase rapidly. Mobile commerce will become the main future cross-border electricity power, small and medium-sized enterprises through the use of the third-party mobile client platform or develop cross-border electricity APP, end to cooperate with each other with computer, the combination of development. (3) Cross-border electricity industry, the ecological environment will be more perfect. For many small and the medium-sized enterprises, such problems as lack of cross-border electricity business talent, will ease, many specialized cross-border electricity business services companies will be more and more, more and more segments. From the platform choice, the products on the Internet, models, web editor, call center, payment, logistics, express delivery, even the overall operations of the cross-border electricity can be outsourced. The cross-border electricity is so small and medium-sized enterprises are not only to choose platform, but on basis of the perfection of the whole cross-border electricity environment, upstream and downstream of the lead and support as to subvert the traditional 
operation mode and achieve sustained rapid growth.

\section{Conclusion}

In this paper, we conduct research on the economic strategy of cross-border electronic commerce for the middle and small-sized enterprises. Cross-border electricity application around the small and the medium-sized enterprises, this paper combined with small and medium-sized enterprise electronic commerce development and the change of the e-commerce market in the past two years, both at home and the abroad through scientific research and the analysis, reflects the current cross-border strategic development direction of the electric business of small and medium-sized enterprises and small and medium-sized enterprise demand for cross-border electric business platform, cross-border electronic business for small and medium enterprises development research and practical work to provide the reference which will promote the future developmental pattern.

\section{References}

[1] Qi, L. I. U., et al. "On the Feasibility of Introducing the" Negative List" Mode to the Cross-border Electronic Commerce." Value Engineering 32 (2014): 129.

[2] Pang, Yusong, and Gabriel Lodewijks. "Design of electronic commerce infrastructure for cross-border postal operations." Service Operations and Logistics, and Informatics (SOLI), 2014 IEEE International Conference on. IEEE, 2014.
[3] MENG, Xiang-ming, and Qian-hui TANG. "Status quo and countermeasure analysis of electronic commerce of of cross-border trade in China." Journal of Shenyang University of Technology (Social Science Edition) 2 (2014): 007.

[4] Yang, Jianzheng, Nachuan Yang, and Lifan Yang. "The Factors Affecting Cross-border E-commerce Development of SMEs---An Empirical Study." (2014).

[5] Sinkovics, Rudolf R., and Daekwan Kim. "The impact of technological, organizational and environmental characteristics on electronic collaboration and relationship performance in international customer-supplier relationships." Information \& Management 51.7 (2014): 854-864.

[6] Turban, Efraim, et al. "Retailing in Electronic Commerce: Products and Services." Electronic Commerce. Springer International Publishing, 2015. 103-159.

[7] Luna-Reyes, Luis Felipe, et al. "Collaborative Cross-Border Security Infrastructure and Systems: Identifying Policy, Managerial and Technological Challenges." International Journal of E-Politics (IJEP) 4.2 (2013): 21-38.

[8] Klassen, Kenneth J., Stacie K. Laplante, and Carla Carnaghan. "A model of multinational income shifting and an application to tax planning with e-commerce." The Journal of the American Taxation Association 36.2 (2014): 27-53. 